\title{
Cetacean Strandings in the Canadian Maritime Provinces, 1990-2008
}

\author{
Leah NemirofF $^{1}$, Tonya Wimmer ${ }^{2}$, Pierre-Yves Daoust ${ }^{3}$, and Donald F. McAlpine ${ }^{4}$ \\ ${ }^{1}$ Biology Department, Dalhousie University, 1355 Oxford Street, Halifax, Nova Scotia B3H 4J1 Canada \\ ${ }^{2}$ Marine Animal Response Society, c/o Nova Scotia Museum, 1747 Summer Street, Halifax, Nova Scotia B3H 3A6 Canada \\ ${ }^{3}$ Canadian Cooperative Wildlife Health Centre, Atlantic Veterinary College, University of Prince Edward Island, 550 Uni- \\ versity Avenue, Charlottetown, Prince Edward Island C1A 4P3 Canada \\ ${ }^{4}$ New Brunswick Museum, 277 Douglas Avenue, Saint John, New Brunswick E2K 1E5 Canada
}

Nemiroff, Leah, Tonya Wimmer, Pierre-Yves Daoust, and Donald F. McAlpine. 2010. Cetacean strandings in the Canadian
Maritime provinces, 1990-2008. Canadian Field-Naturalist 124(1): 32-44.

Organized cetacean stranding networks function to respond quickly and efficiently to strandings, to coordinate live releases, to gather and analyze data, and to educate the public. Stranding networks in the three Canadian Maritime provinces (New Brunswick, Nova Scotia, and Prince Edward Island) recently cooperated to form the Marine Animal Response Network. The resulting collaborative database provides an opportunity to assess patterns of cetacean strandings encompassing 19 years (1990-2008 inclusive) from across the region. During this period, a total of 640 stranding events involving 19 species and 881 individuals of both sexes and varying age groups were reported. Stranding events primarily involved single animals, although several mass strandings were recorded, the largest involving 60 Long-finned Pilot Whales (Globicephala melas). The number of strandings was found to vary substantially over time and among the three provinces. In part, this is likely a reflection of differences in local network effort among regions. Most animals were found dead ashore. Entanglement in fishing gear occurred in over $10 \%$ of the incidents. Relatively more mysticetes were found dead ashore or at sea and entangled in fishing gear than expected by chance, while more odontocetes were found stranded alive than expected. Harbour Porpoises (Phocoena phocoena) appear to be especially vulnerable to entanglement in fishing gear. Necropsies, performed on a subsample of the stranded animals, suggest that Harbour Porpoises die significantly more often from disease than mishap, while Long-finned Pilot Whales and Atlantic White-sided Dolphins (Lagenorhynchus acutus) suffer equally from mishap and disease. Refloating was attempted for $23 \%$ of animals, with an apparent success rate of $83 \%$, although there are no data on long-term survival. Neither sex nor age of the refloated animals was found to be an indicator of subsequent short-term survival.

Key Words: cetaceans, Atlantic White-sided Dolphin, Lagenorhynchus acutus, Harbour Porpoise, Phocoena phocoena, Longfinned Pilot Whale, Globicephala melas, incidental catch, stranding, Maritimes, Canada.

Cetacean strandings occur on coasts around the world and can range from incidents involving single animals to mass strandings of two or more animals, sometimes involving hundreds of individuals (e.g., Dudok van Heel 1962). Strandings of single animal are the most common, although mass strandings may occur frequently in some regions, and almost exclusively involve odontocetes (Geraci 1978; Sergeant 1982).

The causes of cetacean strandings are still poorly understood; see Brabyn (1991) and Goold et al. (2002) for reviews. Many strandings, especially those of one or two animals, are often attributed to disease, parasitism, or old age (Dailey and Walker 1978; Jauniaux et al. 1997; Evans et al. 2005), entanglement with fishing gear (Félix et al. 1997; Hooker et al. 1997), other injuries (Walsh et al. 1991), or disorientation caused by environmental conditions (Mignucci-Giannoni et al. 1999; Walker et al. 2005). The causes of mass stranding events are even less clear, as they are often complicated by the presence of seemingly healthy individuals within the stranded group (e.g., Brabyn and McLean 1992).

It has been suggested that anthropogenic activities, including military sonar (Simmonds and Lopez-Jurado
1991; Parsons et al. 2000) and seismic activity (Engel et al. 2004), may play a role in cetacean mass strandings by disorienting the animals, increasing stress levels, and inducing gas and fat emboli (Balcomb and Claridge 2001; Fernández et al. 2005). Other possible explanations include coastal topography, such as acoustical "dead zones" that cause odontocete echolocation signals to be severely distorted by geomagnetic effects (Dudok van Heel 1962; Brabyn and McLean 1992; Sundaram et al. 2006); large-scale climatic events (Mignucci-Giannoni et al. 1999); solar and lunar cycles (Vanselow and Ricklefs 2005; Wright 2005); toxicity from pollutants (Bouquegneau et al. 1997; Joiris et al. 1997); and social cohesion (Cordes 1982). Stranding events may also be a consequence of several of these factors acting synergistically (MignucciGiannoni et al. 1999; Goold et al. 2002).

An increase in public interest in whales during the last few decades and a desire to study and assist stranded animals have fueled the recent formation of organized stranding networks. Stranding networks exist to provide rapid and effective action in the best interests of live stranded animals, to protect and educate the public, and to gain the maximum amount of scientific information possible from any stranding event (Geraci 
and Lounsbury 2005). For some rare cetaceans, most of what is known about the biology of these species has been gleaned from stranded animals (e.g., Kenyon 1961). Ideally, volunteers and paid personnel are trained to respond quickly and effectively to strandings, to coordinate refloating efforts when possible, to collect information, and to provide liaison with the public. Systematic efforts are made to collect, compile, and analyze data from all stranding events.

There are four principal organizations that collect stranding information and participate in refloating attempts in the three Canadian Maritime provinces (Nova Scotia, New Brunswick, and Prince Edward Island): (1) the Marine Animal Response Society (MARS) in Nova Scotia, (2) the New Brunswick Museum, (3) the Grand Manan Whale and Seabird Research Station (GMWSRS) in New Brunswick; and (4) the Atlantic Veterinary College, University of Prince Edward Island. The Marine Animal Response Network of Atlantic Canada (MARNAC) is a cooperative effort among these groups and others.

Data collected by stranding networks may be useful in monitoring the status, distribution, and seasonal abundance of species (e.g., Osborne and Ransom 1988; Ferrero et al. 1994; Evans and Hammond 2004; Norman et al. 2004; Maldini et al. 2005). For instance, in an analysis of 65 years of data collected from both odontocete stranding events and live surveys, Maldini et al. (2005) found that stranding records are a good indicator of species composition and they produce reliable data on the occurrence of species in a region. Information from strandings can also be used to facilitate management by recording unusual mortality events (Le Boeuf et al. 2000; Norman et al. 2000), reporting species previously unidentified in a region (Ferrero and Tsunoda 1989), and monitoring occurrences of human-cetacean interaction (e.g., entanglement and ship strikes) (Gearin et al. 1994; Hooker et al. 1997). Investigation of strandings may also be an effective means of monitoring measures implemented to reduce threats to species (e.g., to monitor changes in the incidence of vessel strikes in areas after shipping lanes have been moved). Samples from strandings also provide valuable information on anatomy and taxonomy, as well as on parasites, dietary habits, toxicology, and reproduction (Hooker et al. 1997; McAlpine et al. 1997; Norman et al. 2004).

Although some significant individual stranding events in the Maritimes have been recorded in the literature (Piers 1923; Mitchell and Kozicki 1975; McAlpine 1985; McAlpine et al. 1997; Lawson and Eddington 1998; McAlpine et al. 1999; McAlpine and Rae 1999), little comprehensive information on cetacean strandings in the region has been published. Hooker et al. (1997) provided a summary of the cetacean strandings in Nova Scotia covering the period 19911996, and Lucas and Hooker (2000) reviewed stranding events on Sable Island, Nova Scotia, for around the same period. While several studies have used information on strandings in the Maritimes to evaluate the status of individual species in Canada (e.g., Nelson and Lien 1996), a comprehensive review of the strandings recorded for Nova Scotia, New Brunswick, and Prince Edward Island has not previously been attempted. Here we report patterns of cetacean strandings in the three Canadian Maritime provinces from 1990 to 2008 inclusive through analysis of spatial and temporal distribution. We also examine the occurrence of types of stranding incidents and the causes of cetacean mortality across suborders and families. Finally, we determine the survival rate of odontocete species after refloating.

\section{Methods \\ Stranding reports}

Reports of strandings of dead or alive cetaceans were assembled initially by the Marine Animal Response Society, the Atlantic Veterinary College, and the New Brunswick Museum. Records of strandings collected by the Grand Manan Whale and Seabird Research Station, mainly of Harbour Porpoises (Phocoena phocoena) found dead in fishing weirs around Grand Manan Island, constitute a separate set of regionally focused data that have not been incorporated into this study (GMWSRS 2001). Sampling effort varied across stranding events, depending on the availability of volunteers, the accessibility of sites, the state of funding for each of the organizations, the equipment that was available, and the physical condition of the cetacean upon discovery. At a minimum, cetacean taxon (ideally to species), date, location, and incident type were recorded for each stranding event. Whenever possible, photographs were used to confirm species identification, especially when an experienced marine mammologist could not attend an incident. Incident type was identified as fishing gear if the animal was observed offshore entangled or entrapped in fishing gear, as a live stranding if the animal was found alive onshore, as a beaching if the animal was found dead onshore, as dead at sea if the animal was found dead offshore, and as natural entrapment if the animal was found trapped in ice. We also use the more general term stranding throughout this paper to encompass all of the incident types defined above. If members of a stranding network were present, additional information was collected, including on-site confirmation of species, age category (immature, adult), body measurements, sex, and the results of refloating attempts. Where possible, a complete necropsy by a veterinary pathologist was also completed on dead animals (refer to Geraci and Lounsbury (2005) for sampling methodology).

Temporal distribution and provincial occurrence of strandings and incident types

To determine the spatial distribution of cetacean stranding events over time and the occurrence of incident types, one-way contingency tables with associated Pearson chi-square tests $(\alpha=0.05)$ were used. For 
stranding and spatial distribution, the monthly and yearly frequencies of events for each family and suborder were calculated and compared to their expected frequencies based on a chi-square distribution. The length of shoreline for each province was taken from Natural Resources Canada (2000*), with the different amounts of shoreline per province controlled for by incorporating the relative amount of shoreline $(\mathrm{km})$ of each into the expected values (e.g., [shoreline ${ }_{\mathrm{NS}}$ / shoreline $\left._{\text {Total }}\right]^{*}$ total species ${ }_{\mathrm{A}}$ ). Strandings were also mapped and examined visually for areas of concentration. There were no mixed-species stranding events recorded, and all individuals within mass strandings were labeled as the same incident type. Thus, stranding events were used in this analysis rather than stranded individuals, avoiding the likely non-independence of individual data. The natural entrapment incident type was excluded from the analysis due to sparseness of the data.

Linear regressions using least squares were calculated on the square root transformed variables for number of strandings to determine whether the number of incident types for each suborder and family increased or decreased between 1990 and 2008. ANOVAs were used to determine the significance of the regressions. Independence was verified by calculating DurbinWatson D statistics among residuals, and Lilliefors test was used to test residuals for normality. The residuals were plotted against the predicted values to verify that the assumptions of linearity and homoscedasticity were met. Balaenidae, Monodontidae, Physeteridae, and Ziphiidae were excluded from these analyses, since expected frequencies were too low $(<5)$ to permit the estimation of useful probabilities (Hill and Lewicki 2006).

\section{Causes of mortality}

Partial or full necropsies were performed by a veterinary pathologist on many of the carcasses of stranded animals. Detailed information on 105 animals is included in this study: 56 Harbour Porpoises, 37 Atlantic White-sided Dolphins (Lagenorhynchus acutus), and 12 Long-finned Pilot Whales (Globicephala melas) [ $n=4$ (Nova Scotia), 3 (New Brunswick), 98 (Prince Edward Island)]. Depending on the state of preservation of the carcass, gross examination of these animals was complemented by microscopic, bacteriological, and parasitological examination.

Categories of mortality identified included disease, anthropogenic, mishap, and unknown. Disease was defined as any condition that was considered sufficient to have killed the animal or to have weakened it such that it might strand. Acute or chronic infection, chronic trauma causing incapacitation leading to gradual starvation and poor nutritional condition, and poor nutritional condition of undetermined cause were included in this category. Anthropogenic causes included evidence of entrapment in fishing gear or collision with boats. Animals were considered to have died from mishap under the following circumstances: they were found alive onshore during or following certain adverse environmental conditions (e.g., strong onshore wind and high tide) and necropsy revealed no evidence of an underlying disease process following death or euthanasia. A few animals found dead ashore were also included in this category if environmental circumstances at the time suggested the preceding as a likely cause. Most animals found dead ashore with no evidence of disease were considered to have died of an unknown cause; advanced postmortem decomposition was partly responsible for some of these unknown causes of death.

One-way contingency tables with associated Pearson chi-square tests $(\alpha=0.05)$ were used to examine the distribution of causes of mortality (disease or mishap) for each of the three species included in this analysis. Due to the few cases where necropsy identified anthropogenic causes as leading to death, this category was excluded from analysis. Animals for which the cause of mortality was unknown were also excluded. The causes of mortality were compared between species using one-way contingency tables with associated Pearson chi-square tests $(\alpha=0.05)$. Long-finned Pilot Whales were excluded from this part of the analysis due to the low sample size of these whales that were necropsied.

\section{Short-term survival after refloating}

A refloating (live release) event was considered successful when a live stranded animal, after being pushed back into deeper water, was observed to swim away without immediately restranding; the long-term survival of such animals was not observed. In order to determine whether any variables can be used to predict the success of odontocete refloating attempts, a complete logistic regression, with sex and age categories as the independent variables, was applied to the data with 50 iterations. All odontocetes for which refloating was attempted and for which sex and age data were available were included in the analysis $(n=205)$. Mysticetes were excluded from the analysis, as it is extremely rare that a baleen whale is small enough for refloating to be attempted. The significance of the model was determined through a log-likelihood test. McFadden's rho was used to compare the likelihood for the constant-only model to the likelihood for the model with the predictor (Hill and Lewicki 2006). All analyses were done using the statistical package SYSTAT 12.

\section{Results \\ Stranding events}

There were a total of 640 stranding events recorded for the Maritimes during 1990-2008, involving 19 species and 881 individuals of both sexes and varying age groups (Table 1). The majority of strandings $(61 \%)$ involved Atlantic White-sided Dolphin (23\%), Harbour Porpoise $(21 \%)$ or Long-finned Pilot Whale 
TABLE 1. Species (grouped by family), sex, and age category of cetaceans stranded in Nova Scotia (NS), New Brunswick (NB), and Prince Edward Island (PEI) from 1990 to 2008.

\begin{tabular}{|c|c|c|c|c|c|c|c|c|c|c|c|}
\hline \multirow[b]{2}{*}{ Species } & \multicolumn{5}{|c|}{ Stranding events } & \multicolumn{3}{|c|}{ Individuals (sex) } & \multicolumn{3}{|c|}{ Individuals (age category) } \\
\hline & Total & NS & NB & PEI & Unknown & Male & Female & Unknown & Adult & Immature & Unknown \\
\hline \multicolumn{12}{|l|}{ Delphinidae } \\
\hline Lagenorhynchus acutus & 204 & 84 & 5 & 115 & 0 & 17 & 45 & 142 & 41 & 10 & 153 \\
\hline Tursiops truncatus & 1 & 1 & 0 & 0 & 0 & 0 & 0 & 1 & 0 & 0 & 1 \\
\hline Delphinus capensis & 3 & 3 & 0 & 0 & 0 & 0 & 0 & 3 & 0 & 0 & 3 \\
\hline Delphinus delphis & 3 & 2 & 1 & 0 & 0 & 2 & 1 & 0 & 1 & 0 & 2 \\
\hline Stenella coeruleoalba & 15 & 15 & 0 & 0 & 0 & 6 & 5 & 4 & 0 & 1 & 14 \\
\hline Lagenorhynchus albirostris & 5 & 4 & 0 & 1 & 0 & 3 & 0 & 2 & 1 & 0 & 4 \\
\hline $\begin{array}{l}\text { Globicephala melas } \\
\text { Balaenidae }\end{array}$ & 153 & 125 & 3 & 25 & 0 & 20 & 23 & 110 & 17 & 12 & 124 \\
\hline $\begin{array}{l}\text { Eubalaena glacialis } \\
\text { Balaenopteridae }\end{array}$ & 17 & 7 & 4 & 0 & 6 & 6 & 2 & 9 & 3 & 4 & 10 \\
\hline Balaenoptera physalus & 31 & 13 & 5 & 11 & 2 & 5 & 3 & 23 & 5 & 3 & 23 \\
\hline Megaptera novaeangliae & 32 & 26 & 2 & 0 & 4 & 5 & 2 & 25 & 1 & 3 & 28 \\
\hline Balaenoptera acutorostrata & 58 & 38 & 6 & 13 & 1 & 13 & 6 & 39 & 10 & 8 & 40 \\
\hline $\begin{array}{l}\text { Balaenoptera borealis } \\
\text { Monodontidae }\end{array}$ & 8 & 7 & 0 & 1 & 0 & 0 & 1 & 7 & 1 & 0 & 7 \\
\hline $\begin{array}{l}\text { Delphinapterus leucas } \\
\text { Phocoenidae }\end{array}$ & 7 & 2 & 5 & 0 & 0 & 1 & 3 & 3 & 2 & 0 & 5 \\
\hline $\begin{array}{l}\text { Phocoena phocoena } \\
\text { Physeteridae }\end{array}$ & 186 & 54 & 65 & 64 & 3 & 64 & 65 & 57 & 39 & 47 & 100 \\
\hline Kogia sima & 1 & 1 & 0 & 0 & 0 & 0 & 1 & 0 & 0 & 0 & 1 \\
\hline Kogia breviceps & 6 & 5 & 1 & 0 & 0 & 1 & 2 & 3 & 0 & 1 & 5 \\
\hline $\begin{array}{l}\text { Physeter macrocephalus } \\
\text { Ziphiidae }\end{array}$ & 49 & 28 & 5 & 16 & 0 & 4 & 21 & 24 & 2 & 9 & 38 \\
\hline Hyperoodon ampullatus & 2 & 2 & 0 & 0 & 0 & 1 & 1 & 0 & 0 & 1 & 1 \\
\hline Mesoplodon bidens & 2 & 1 & 1 & 0 & 0 & 2 & 0 & 0 & 0 & 0 & 2 \\
\hline Unknown species & & & & & & & & & & & \\
\hline Unidentified mysticete & 8 & 7 & 0 & 1 & 0 & 0 & 0 & 8 & 0 & 0 & 8 \\
\hline Unidentified odontocete & 18 & 18 & 0 & 0 & 0 & 0 & 0 & 18 & 0 & 0 & 18 \\
\hline Unidentified cetacean & 72 & 56 & 1 & 4 & 11 & 0 & 1 & 71 & 0 & 0 & 72 \\
\hline Total & 881 & 499 & 104 & 251 & 27 & 150 & 182 & 549 & 123 & 99 & 659 \\
\hline
\end{tabular}

(17\%). For the most part, stranding events were of single animals (93\%). However, 22 events involved 2 animals (3.4\%), and 17 events were composed of 3-8 animals $(2.7 \%)$. Five stranding events involved more than 10 animals $(0.8 \%), 4$ of which involved Atlantic White-sided Dolphins (14, 15, 26, and 40 animals). The largest mass stranding was composed of 60 LongFinned Pilot Whales. There were no mixed-species strandings recorded during the time period considered here.

\section{Temporal distribution of strandings}

There was significant variability in the monthly and annual distribution of stranding events when examined by suborder (Table 2). The number of strandings involving odontocetes peaked in 1993 (Figure 1a); stranding of odontocetes occurred most often in late summer, with an increased number of stranding events in August (Figure 2a). Among odontocetes, Harbour Porpoises accounted for the majority of strandings in 1993, and Sperm Whales (Physeter macrocephalus) were recorded stranding most often in 2005. Strandings of dolphin species varied considerably between years without any obvious peak year (Figure 1b). Lin-
TABLE 2. Chi-square values for the number of stranding events in the Maritimes for each suborder.

\begin{tabular}{lccc}
\hline \hline Contingency table & $\chi^{2}$ & $\mathrm{df}$ & $P$ \\
\hline Mysticete - Month & 47.392 & 11 & $<0.001$ \\
Mysticete - Year & 58.235 & 18 & $<0.001$ \\
Odontocete - Month & 226.545 & 11 & $<0.001$ \\
Odontocete - Year & 92.178 & 18 & $<0.001$ \\
\hline \hline
\end{tabular}

ear regression suggests that there is no consistent trend in odontocete strandings over time (Table 3). However, Harbour Porpoise data were highly skewed, as some years had much higher numbers of reported strandings than others. When examined by month, both Harbour Porpoises and the dolphin species were encountered stranded most often in late summer (Figure 2b). Sperm whales, conversely, were recorded stranding throughout the year, although with a higher number of events in winter (Figure 2b).

Strandings involving mysticetes followed a similar pattern, varying significantly over the years and months. There was a peak in 2006 (Figure 1a) and an increase in reported strandings in late summer (Figure 2a). With- 

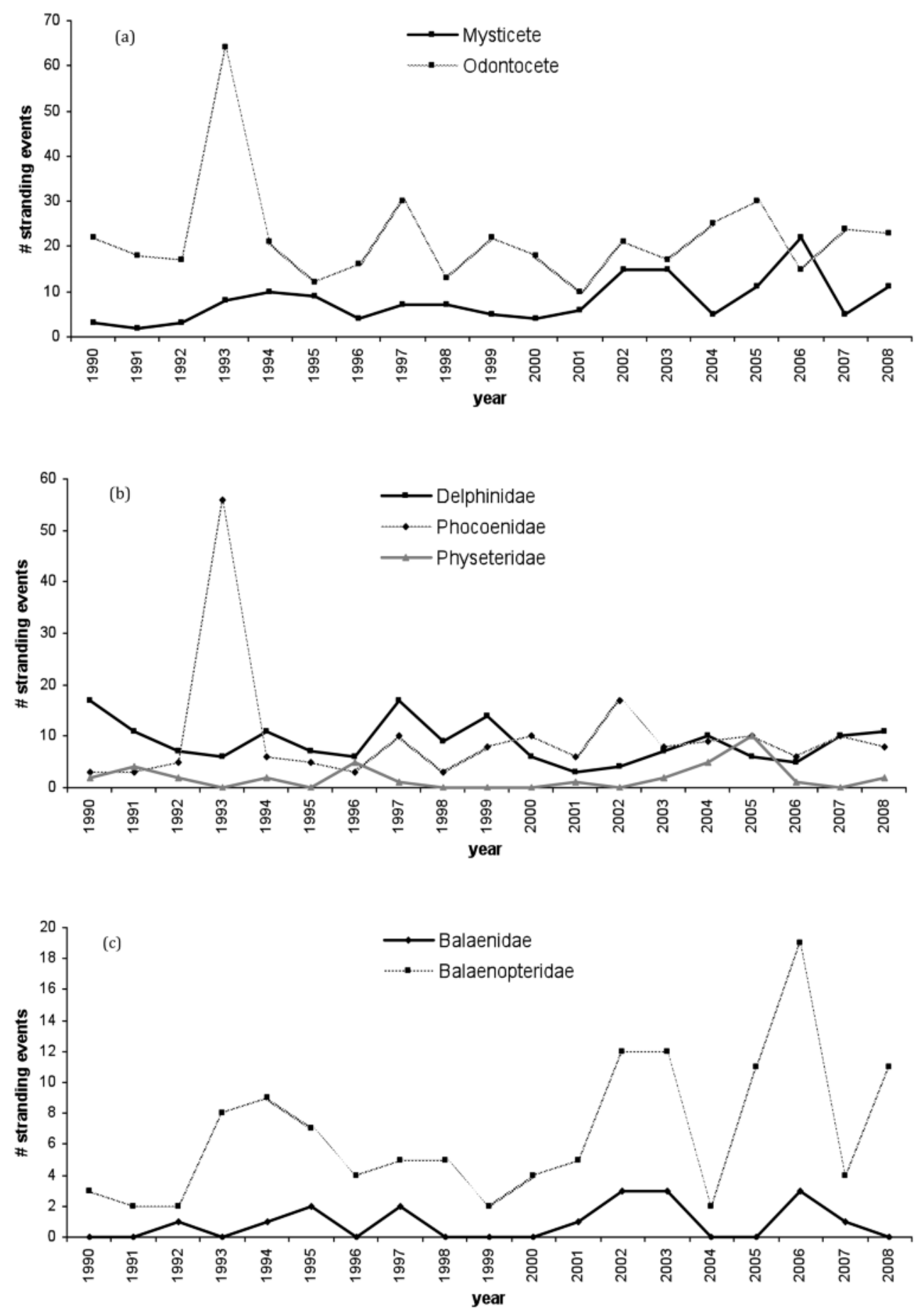

FIGURE 1. The proportion of total stranding events involving (a) mysticetes and odontocetes, (b) delphinids, phocoenids, and physeterids, and (c) balaenids and balaenopterids per year, recorded for the Maritimes, 1990-2008. 
TABLE 3. Linear regression results for the number of stranding events in the Maritimes per family and suborder. Variables were square-root (SQR) transformed to meet the assumption of normality when possible. Significant values $(P<0.05)$ are in bold.

\begin{tabular}{lrrrrrrr}
\hline \hline Variable & \multicolumn{1}{c}{$\beta_{0}$} & \multicolumn{1}{c}{$\beta_{1}$} & $r^{2}$ & $r^{2}($ adj.) & \multicolumn{1}{c}{$P$} & D-Watson & Lilliefors $P$ \\
\hline SQR (Mysticete) & -165.335 & 0.084 & 0.309 & 0.269 & $\mathbf{0 . 0 1 3}$ & 2.025 & 0.581 \\
SQR (Odontocete) & 33.373 & -0.014 & 0.006 & $<0.001$ & 0.750 & 2.266 & 0.232 \\
SQR (Balaenopteridae) & -144.813 & 0.074 & 0.234 & 0.189 & $\mathbf{0 . 0 3 6}$ & 2.108 & 0.948 \\
SQR (Delphinidae) & 68.873 & -0.033 & 0.078 & 0.023 & 0.248 & 1.538 & 0.377 \\
SQR (Phocoenidae) & -29.315 & 0.016 & 0.005 & $<0.001$ & 0.774 & 2.196 & $<0.001$ \\
\hline \hline
\end{tabular}

in the mysticetes, North Atlantic Right Whale (Eubalaena glacialis) strandings were recorded most often in 2002-2003 and 2006, while balaenopterid species strandings peaked in 2006 (Figure 1c). When examined by month, both the North Atlantic Right Whale and the balaenopterids were recorded stranding most often in late summer (Figure 2c), the period during which these species are most abundant in waters in the Maritimes. The number of mysticete strandings appears to have increased slightly from 1990 to 2008, although this may in part be due to the relatively high number of strandings observed in 2006 (Table 3, Figure 1a) and perhaps the increasingly organized effort to record strandings in recent years.

\section{Provincial occurrence of strandings}

There is also a significant amount of variability in the incidence of stranding events by province within the Maritimes (Figure 3), when examined both by suborder and by family (Table 4). Prince Edward Island had more stranding events than expected by chance alone, even when controlling for the amount of shoreline (Table 5). More strandings off New Brunswick involved Harbour Porpoises than expected, while more balaenopterid and delphinid strandings occurred off Nova Scotia than expected by chance (Table 5). Although Figure 3 does show that stranding events were well distributed along provincial coastlines, there appear to be concentrations of events in the outer Bay of Fundy and in the Halifax region.

\section{Occurrence of incident types}

Of the cetaceans stranded across the Maritimes, most were found beached (48\%) or live stranded (34\%). Entanglement in fishing gear was the primary
TABLE 4. Chi-square test values for the number of stranding events per suborder and family across the Maritime provinces.

\begin{tabular}{lccc}
\hline \hline Contingency table & $\chi^{2}$ & df & $P$ \\
\hline Mysticete - Province & 15.529 & 1 & $<0.001$ \\
Odontocete - Province & 142.665 & 1 & $<0.001$ \\
Balaenopteridae - Province & 18.763 & 2 & $<0.001$ \\
Delphinidae - Province & 83.068 & 2 & $<0.001$ \\
Phocoenidae - Province & 131.360 & 2 & $<0.001$ \\
\hline \hline
\end{tabular}

incident type for $11 \%$ of animals, and $5 \%$ of whales were found dead at sea. There were also two recorded incidents of ice entrapment, both involving Sperm Whales off Nova Scotia.

The occurrence of the different incident types varied significantly between suborders $\left(\chi^{2}=15.25, \mathrm{df}=3\right.$, $P=0.002)$ and across families $\left(\chi^{2}=85.85, \mathrm{df}=6\right.$, $P<0.001)$. Mysticetes were found beached, entangled in fishing gear, or dead at sea more often than expected, but live stranded less frequently than predicted by chance (Table 6). Conversely, odontocetes, more specifically delphinids, were reported stranded alive more often than expected by chance. Harbour Porpoises became entangled in fishing gear and were found dead at sea more often than expected by chance (Table 6).

\section{Causes of mortality}

The causes of mortality of the 105 animals for which detailed necropsy information was available are presented in Table 7. Disease appeared to be the main cause of mortality for Harbour Porpoises (Figure 4), affecting this species significantly more often than mishap $\left(\chi^{2}=13.33\right.$, df $\left.=1, P<0.001\right)$. Although mishap appeared to affect more Atlantic White-sided

TABLE 5. Observed and expected frequencies of stranding events for Nova Scotia (NS), New Brunswick (NB), and Prince Edward Island (PEI) from 1990 to 2008, grouped by suborder and family. The expected values reflect the number of stranding events estimated to occur if the events are influenced by chance alone, and are controlled for the amount of shoreline (km) of each province. Instances in which the observed number of stranding events is higher than predicted are in bold.

\begin{tabular}{|c|c|c|c|c|c|c|}
\hline & \multicolumn{2}{|c|}{ NS } & \multicolumn{2}{|c|}{ NB } & \multicolumn{2}{|c|}{ PEI } \\
\hline & Observed & Expected & Observed & Expected & Observed & Expected \\
\hline Mysticete & 96 & 89 & 17 & 34 & 26 & 16 \\
\hline Odontocete & 207 & 266 & 82 & 101 & 125 & 48 \\
\hline Balaenopteridae & 82 & 77 & 13 & 29 & 25 & 14 \\
\hline Delphinidae & 110 & 107 & 6 & 41 & 51 & 19 \\
\hline Phocoenidae & 54 & 117 & 65 & 45 & 64 & 21 \\
\hline
\end{tabular}



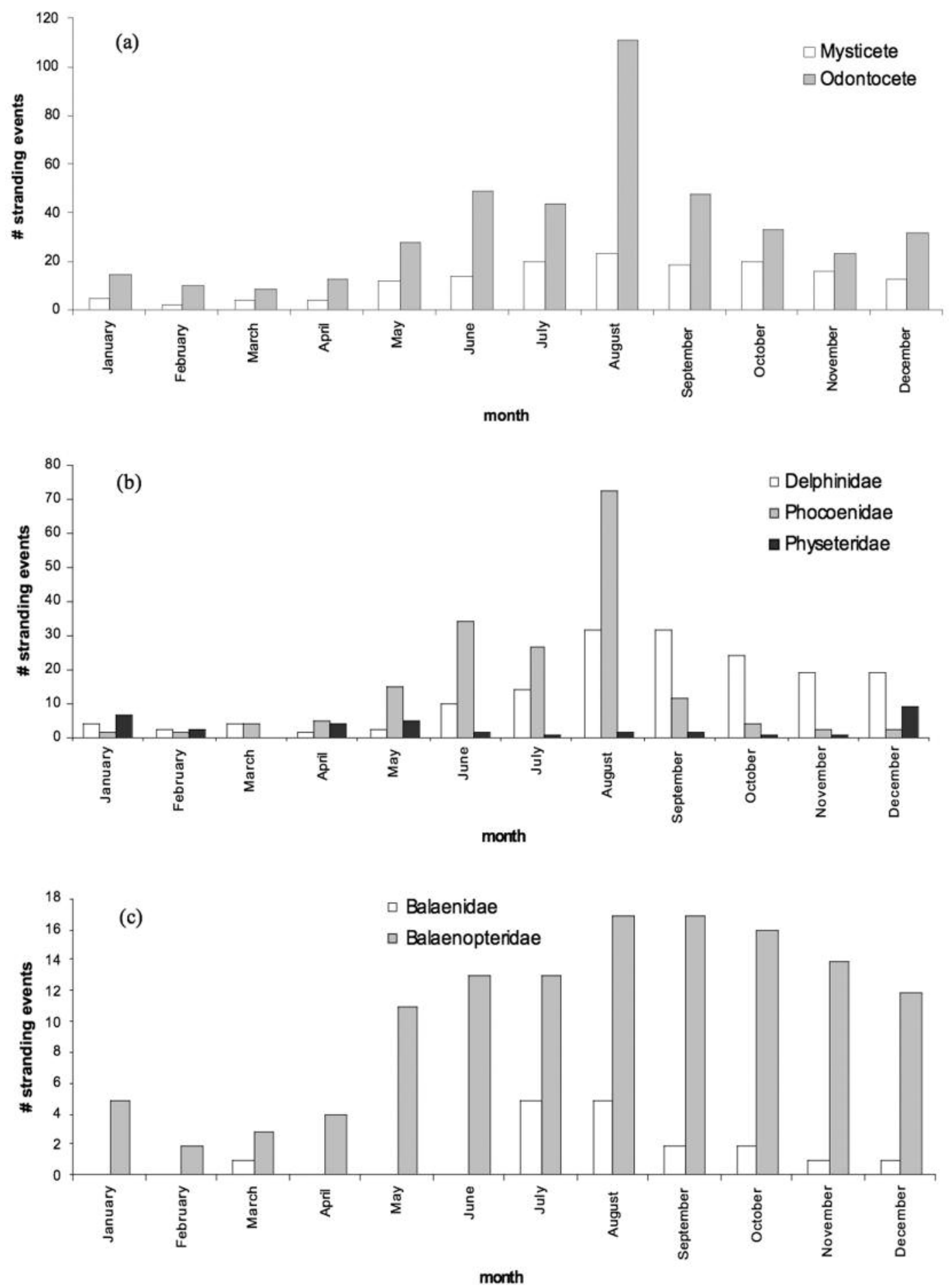

FIGURE 2. The proportion of total stranding events involving (a) mysticetes and odontocetes, (b) delphinids, phocoenids, and physeterids, and (c) balaenids and balaenopterids per month, recorded for the Maritimes, 1990-2008. 


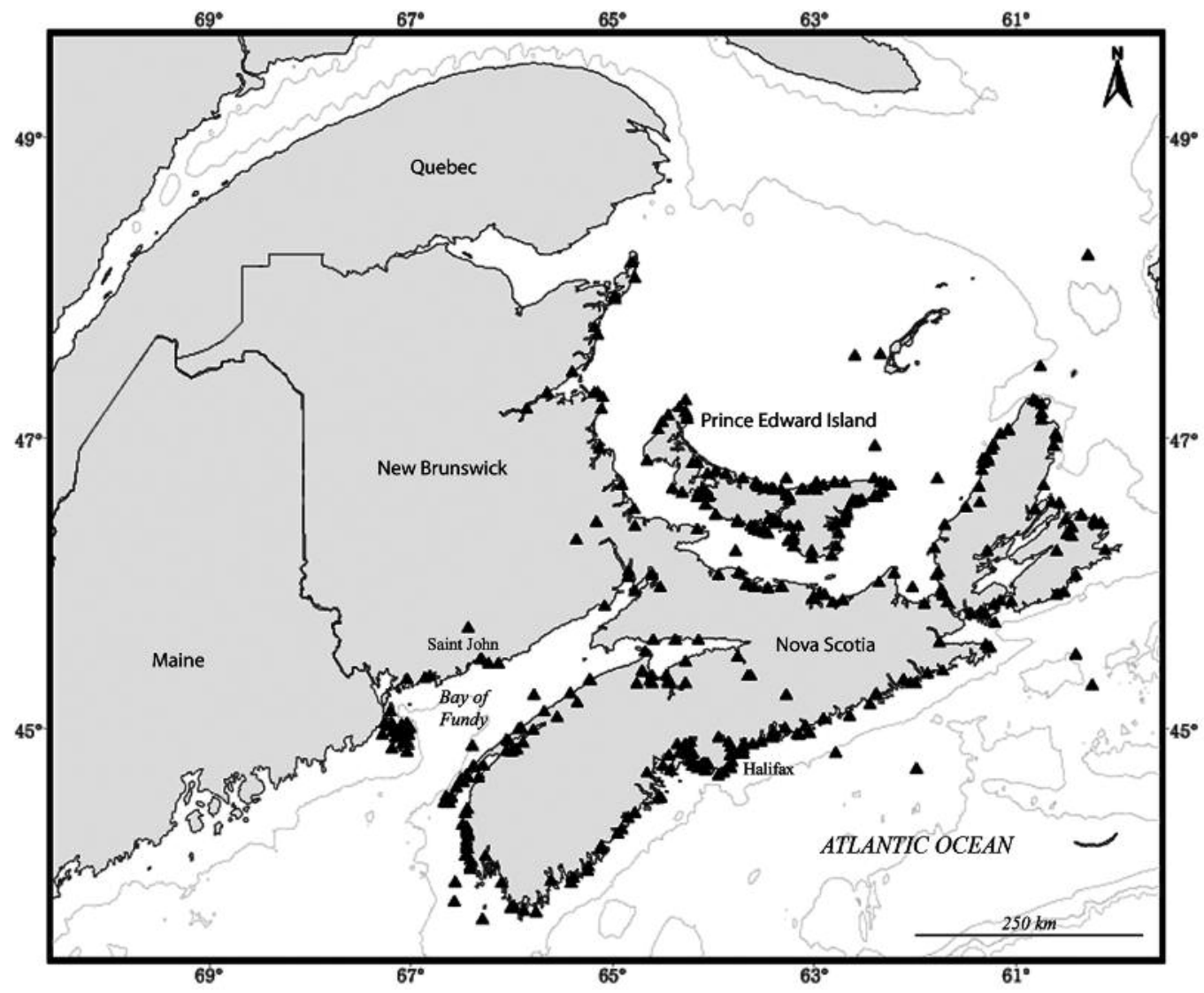

FIGURE 3. Spatial distribution of stranded cetaceans in the Maritimes, 1990-2008 $(n=640)$. Stranding events that appear to be inland are river incidents.

Dolphins and Long-finned Pilot Whales than did disease (Figure 4), this difference was not significant $\left(\chi^{2}=1.64, \mathrm{df}=1, P=0.201\right.$, and $\chi^{2}=2.00, \mathrm{df}=1$, $P=0.157$, respectively). However, only a small number of Long-finned Pilot Whales were necropsied, thus providing an incomplete picture of pathology for this species in the region. Stranded Harbour Porpoises showed more evidence of disease than did Atlantic White-sided Dolphins $\left(\chi^{2}=8.76, \mathrm{df}=1, P=0.003\right)$, while Atlantic White-sided Dolphins were more likely to die from mishap than Harbour Porpoises $\left(\chi^{2}=4.26\right.$, $\mathrm{df}=1, P=0.039$ ).

\section{Refloating attempts}

Refloating attempts were documented for 205 individuals (23\%) over the 19-year period, with an apparent success rate of approximately $83 \%$. The remainder of the animals died, were euthanized, or their fate is unknown. The majority of animals refloated were delphinid species (84\%), primarily Atlantic White-sided
Dolphins and Long-Finned Pilot Whales. Refloating attempts were also made for 10 Harbour Porpoises, 3 Sperm Whales, a Pygmy Sperm Whale (Kogia breviceps), and a Northern Bottlenose Whale (Hyperoodon ampullatus), as well as for 4 mysticetes (2 Humpback Whales, Megaptera novaeangliae, and 2 Minke Whales, Balaenoptera acutorostrata).

Information on both sex and age categories was available for only 23 of the refloated animals ( $6 \mathrm{fe}-$ males, 17 males; 14 adults, 9 immatures). Once refloated, females appear to have a slightly better survival rate than males (Figure 5a), although the sample size is very small and thus should be interpreted with caution. Age does not appear to play an important role in cetacean survival after refloating, although immature whales do appear to have had a slightly lower death rate than adults (Figure 5b). None of the parameters included in the logistic regression could be attributed to differential success of refloating events (Table 8). Thus, neither the sex nor the age category of a whale 
TABLE 6. Observed and expected frequencies of stranding events for each incident type from 1990 to 2008, grouped by suborder and family. The expected values reflect the number of stranding events estimated to occur if the events are influenced by chance alone. Instances in which the observed number of stranding events is higher than predicted are in bold.

\begin{tabular}{|c|c|c|c|c|c|c|c|c|}
\hline & \multicolumn{2}{|c|}{ Beached } & \multicolumn{2}{|c|}{ Stranded } & \multicolumn{2}{|c|}{ Anthropogenic } & \multicolumn{2}{|c|}{ Dead at sea } \\
\hline & Observed & Expected & Observed & Expected & Observed & Expected & Observed & Expected \\
\hline Mysticete & 102 & 95 & 11 & 25 & 24 & 21 & 14 & 9 \\
\hline Odontocete & 252 & 259 & 83 & 69 & 55 & 58 & 21 & 26 \\
\hline Balaenopteridae & 89 & 78 & 11 & 22 & 17 & 19 & 9 & 7 \\
\hline Delphinidae & 101 & 102 & 57 & 29 & 4 & 25 & 4 & 10 \\
\hline Phocoenidae & 103 & 113 & 15 & 32 & 50 & 27 & 15 & 11 \\
\hline
\end{tabular}

TABLE 7. Causes of mortality identified in three species of odontocetes. See text for definition of categories.

\begin{tabular}{lcccr}
\hline \hline & Harbour & Atlantic & Long-finned & Total \\
& Porpoise & White-sided Dolphin & Pilot Whale & 35 \\
\hline Disease & 25 & $8^{2}$ & 2 & 5 \\
Anthropogenic cause & 5 & - & - & 25 \\
Mishap & $5^{1}$ & 14 & 6 & $40(9)$ \\
Unknown (autolysis) & $21(8)$ & $15(1)$ & 4 & 105 \\
Total & 56 & 37 & 12 & \\
\hline \hline
\end{tabular}

${ }^{1}$ Including 4 calves, found between late June and late August, presumably separated from their mother.

${ }^{2}$ Including 3 animals diagnosed with bacteremia/septicemia caused by Vibrio sp., possibly secondary to stranding by mishap.

can be used to predict the success of a refloating attempt at this time. However, a larger sample size may reveal patterns that are not evident with the sample size considered here.

\section{Discussion}

The majority of cetacean strandings in the Canadian Maritime provinces appear to be single animal events, with significant variability on an annual scale. These data agree with those reported by Hooker et al. (1997), who found that strandings occurred variably throughout Nova Scotia and also varied between years and months. Relatively more strandings occurred in the summer months during our study period. In part, this likely reflects increased reporting effort during the summer, a time when people visit the coastlines most frequently (Hooker et al. 1997; Norman et al. 2004; Evans et al. 2005). However, this pattern may also reflect seasonal movements of small odontocetes that are inshore in the region during the summer months but move to more offshore waters during the winter (e.g., Neave and Wright 1968; Payne and Heinemann 1993). The increase in the number of Sperm Whale strandings reported during the winter months, for instance, may be a consequence of their movement patterns, although these are not yet well resolved (Whitehead 2003). Mass strandings were observed to occur rarely, and were most often composed of Long-finned Pilot Whales or Atlantic White-sided Dolphins. This agrees with previous studies of strandings off Nova Scotia and Newfoundland (Sergeant 1982; Hooker et al. 1997) and may be indicative of the relatively high abundance of those

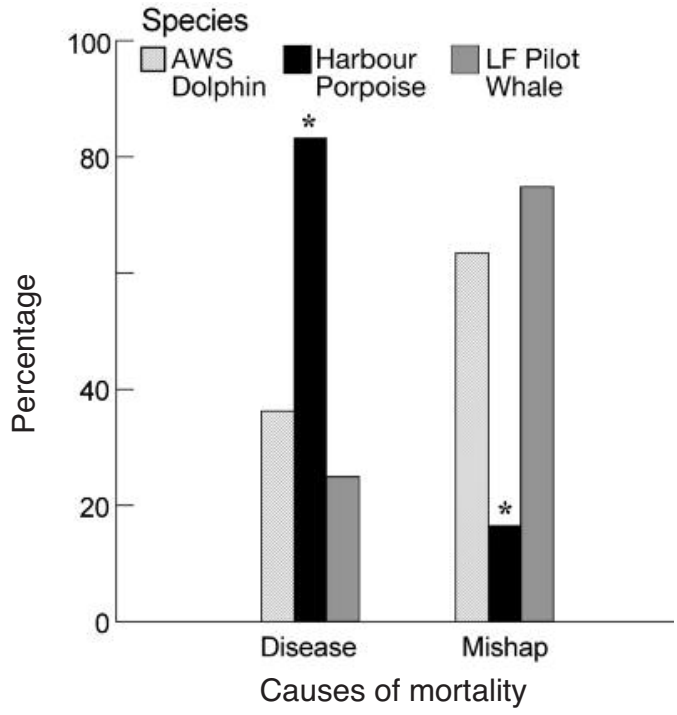

FIGURE 4. The main documented causes of mortality for Atlantic White-sided Dolphins (AWS), Harbour Porpoises (HP), and Long-finned Pilot Whales (LF). Asterisks denote significant differences $(P<0.001)$ between causes of mortality for each species, based on chi-square tests.

two species within waters in the Maritimes (Hooker et al. 1997; Reeves et al. 2002).

While strandings appear to be well distributed along provincial coastlines, there do appear to be slight con- 

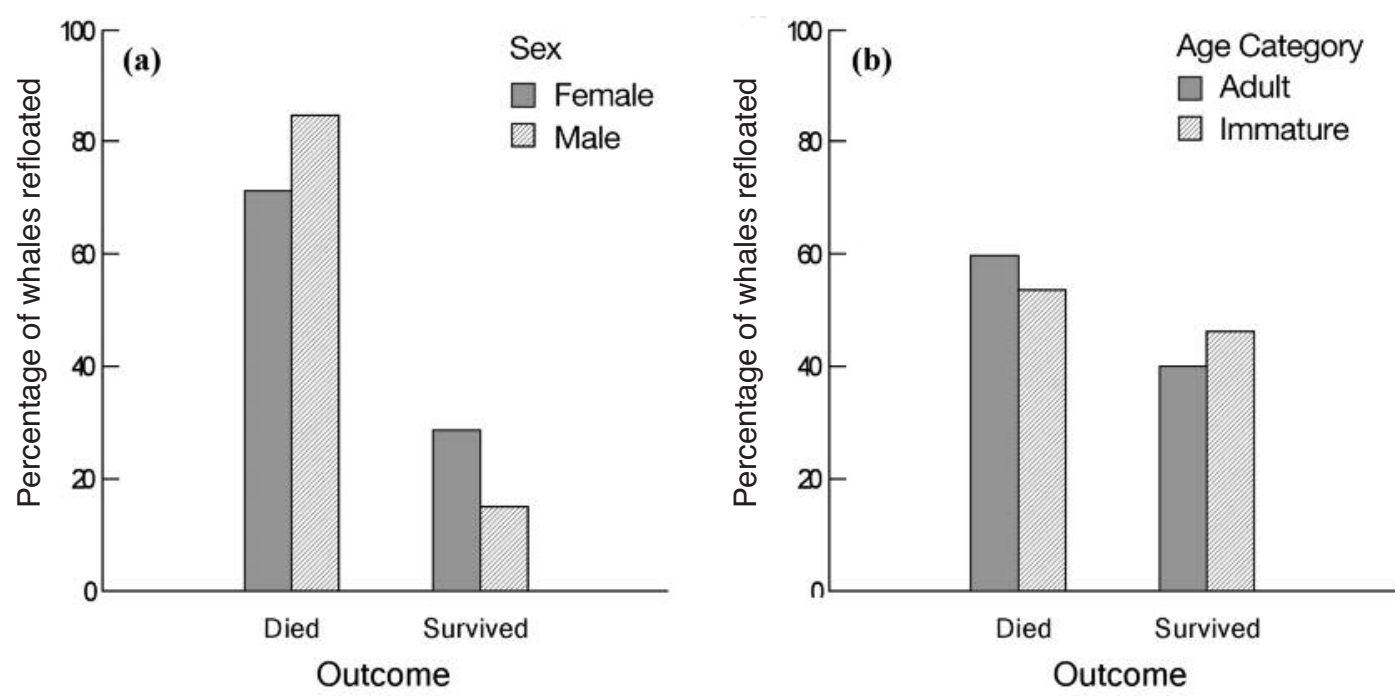

FIGURE 5. Odontocete outcome (died, survived) after refloating attempts: (a) grouped by sex and (b) grouped by age.

centrations of events in the outer Bay of Fundy and in the Halifax region. The Halifax concentration is undoubtedly an artifact of reporting by the Marine Animal Response Society. There is probably some observer bias in the Bay of Fundy as well, with whale researchers concentrated in the outer bay, where whales occur with greatest frequency. Relatively inaccessible coastlines, such as the roadless coastline immediately northeast of Saint John, may contribute to the lack of reported strandings in some areas. The higher number of strandings reported along the coast of Prince Edward Island than expected may be due to high levels of effort, facilitated by the province's small size, accessible shoreline, and locally well-known stranding network at the Atlantic Veterinary College. There may also be a higher proportion of accessible beaches along its coastline, increasing the likelihood that strandings will be noticed by chance observers. Overall, though, it appears that there are as yet not enough data to identify with certainty any areas in the Maritimes that may be particularly prone to live or dead cetacean stranding events.

\section{Incident types}

The number of reported mysticete events involving dead animals (beached or dead at sea) was higher than predicted. The greater number of dead mysticetes reported may be a consequence of their relatively higher buoyancy, resistance to dismemberment by scavengers, and greater visibility (Béland et al. 1987), which increases the likelihood that the animals will be seen by passing vessels or will wash ashore and be encountered by human observers. Conversely, odontocetes appeared to strand alive more often than was predicted by chance alone. This may be due, in part, to the propensity for toothed whales to mass strand (Geraci 1978; Sergeant 1982). The mass stranding events (involving more than two animals) recorded in the Maritimes during the period considered here involved only toothed whales, particularly Atlantic White-sided Dolphins and LongFinned Pilot Whales. Both of these species seem to show a propensity to strand by mishap. During such events, healthy animals within the stranded group may survive longer on shore than animals that strand due to illness or injury, increasing the chance that an observer will record them as stranded alive.

More baleen whales in the Maritimes were observed entangled in fishing gear than predicted by chance alone. This may be a consequence of mysticete foraging strategies, namely bulk foraging by skimming and lunging (Bowen et al. 2002). Such strategies render baleen whales vulnerable to entanglement in longlines, pot trap gear, and other moorings resting near the surface (Northridge 1991; Johnson et al. 2005). Odontocetes, with the exception of Harbour Porpoises, do not appear to become entangled in fishing gear more often than predicted by chance. Incidental catch of Harbour Porpoises, especially in gillnets, was a major cause of concern in the Maritimes during the study period covered here (Trippel et al. 1996). Current efforts are focused on mitigating this negative interaction with local fisheries (e.g., Trippel et al. 1999).

\section{Causes of mortality of necropsied animals}

Disease was identified in a larger proportion of stranded Harbour Porpoise than predicted statistically. Atlantic White-sided Dolphins and Long-finned Pilot Whales, conversely, both appeared to have suffered 
TABLE 8. Complete logistic regression results for the survival of refloated odontocetes of different ages and sexes. The significance of the model is calculated with a log-likelihood test. A McFadden's rho value between 0.2 and 0.4 indicates significant correlation.

\begin{tabular}{|c|c|c|c|c|c|c|c|}
\hline Parameter & Estimate & SE & $Z$ & $P$ & $\begin{array}{l}\text { Log- } \\
\text { likelihood }(\mathrm{df}=2)\end{array}$ & $\begin{array}{l}\text { Log- } \\
\text { likelihood } P\end{array}$ & $\begin{array}{c}\text { McFadden's } \\
\text { rho }^{2}\end{array}$ \\
\hline Constant & -0.882 & 0.746 & -1.18 & 0.237 & -12.042 & 0.272 & 0.108 \\
\hline Sex & 1.537 & 1.32 & 1.165 & 0.244 & & & \\
\hline Age category & -1.658 & 1.261 & -1.31 & 0.189 & & & \\
\hline
\end{tabular}

equally from mishap and disease. There is evidence that the echolocation system of odontocetes typically found offshore or on the continental shelf may be less suitable as a navigational aid in shallow coastal environments than that of inshore or estuarine species, such as Harbour Porpoises (Ketten 1991, 1994; Reeves et al. 2002). Inshore species are more likely to be sick or injured when found stranded, since healthy animals should be adept at navigating in relatively shallow coastal waters. This may have important implications for stranding networks wishing to assist stranded animals. The prospect for successful assistance may be reduced for Harbour Porpoises, which are more likely to be affected by disease or injury when found ashore. Conversely, offshore species such as the Atlantic Whitesided Dolphin and Long-finned Pilot Whale appear to be as likely to strand as a result of mishap as of disease.

\section{Limitations of stranding information and manage- ment implications}

The use of stranding information has inherent limitations (Klinowska 1985). As noted, variation in the number of reported strandings in the Maritimes between provinces and over time may reflect the relative abundance of a species in a region at a given time. Levels of human effort and efficiency in locating and reporting strandings often vary over time and between regions and may also affect the quality of the data. The likelihood that a stranding will be reported is also dependent on physical oceanographic features that bring the body of the animal to shore, such as upwelling and downwelling (Norman et al. 2004). The degree of buoyancy of different species and different body states (healthy or emaciated) and the currents and wind also affect when and where the animal will be found (Norman et al. 2004; Walker et al. 2005). Categories used to describe causes of mortality may often underestimate the effect of human activities on stranding events; while entanglement in fishing gear and ship strikes often result in identifiable external injuries, it is more difficult to link the use of sonar signals in military exercises and seismic surveys to strandings (see Weilgart 2007 for a review; Simmonds and LopezJurado 1991; Engel et al. 2004).

Despite these limitations and the relatively recent efforts to collect cetacean stranding data broadly in the Maritimes, such information has already contributed to knowledge about cetaceans in the waters of the region (e.g., Hooker et al. 1999; Lucas and Hooker 2000; Wimmer 2003). Information on the success rate of refloating attempts can also play a role in the development of rapid and efficient triage strategies, enabling stranding networks to allocate resources most effectively during stranding events (Geraci and Lounsbury 2005). To date, refloating attempts in the Maritimes appear to be largely successful for small odontocetes found alive, but the use of tracking tags on such animals would provide more information on survival and movement patterns after refloating (Geraci and Lounsbury 2005). The continuing collection of such data in the Maritimes may also help in predicting where stranding events are most likely to occur in the future and lead to the development of management strategies. Stranding information on Harbour Porpoise incidental catch has already led to an increased effort to mitigate the effect of fisheries on this species through the development of alternative fishing practices and equipment (e.g., Trippel et al. 1999; Culik et al. 2001).

The provincial stranding networks have only recently developed the central database of stranding event data used in this study. This collaboration should permit more effective information sharing between New Brunswick, Nova Scotia, and Prince Edward Island in the future. It should also play an important role in furthering understanding of both the biology of and the management options for marine mammals in waters of the Maritimes.

\section{Acknowledgments}

We thank the many volunteers, fisheries officers from Fisheries and Oceans Canada, Parks Canada wardens, and provincial Natural Resources officers who work closely with stranding networks in the Maritimes and help respond to incidents, collect data and samples, and maintain the databases. Chuck Gallison, Department of Energy, Environment and Forestry, provided information on stranding events on Prince Edward Island. We also thank Hal Whitehead and an anonymous reviewer for comments and useful feedback on the manuscript. This study was supported financially by the Nova Scotia Marine Animal Response Society, the Government of Canada Habitat Stewardship Program for Species at Risk, and the Canadian Cooperative Wildlife Health Centre, Atlantic Veterinary College, University of Prince Edward Island. 
Documents Cited (marked * in text)

Natural Resources Canada. 2000. Canada Centre for Remote Sensing. GeoAccess Division. http://atlas.nrcan. gc.ca/site/english/learningresources/facts/coastline.html\#c4 [accessed 30 March 2007].

\section{Literature Cited}

Balcomb, K.C., and D. E. Claridge. 2001. A mass stranding of cetaceans caused by naval sonar in the Bahamas. Bahamas Journal of Science 8: 2-12.

Béland, P., D. Martineau, P. Robichaud, R. Plante, and R. Greendale. 1987. Échouages de mammifères marins sur les côtes du Québec dans l'estuaire et le golfe du Saint Laurent de 1982 à 1985. Canadian Technical Report of Fisheries and Aquatic Sciences 1506. 44 pages.

Bouquegneau, J. M., V. Debacker, S. Gobert, and J. P. Nellissen. 1997. Toxicological investigations on four sperm whales stranded on the Belgian coast: inorganic contaminants. Biologie 67 (Supplement): 75-78.

Bowen, W. D., A. J. Read, and J. A. Estes. 2002. Feeding ecology. Pages 217-246 in Marine Mammal Biology: An Evolutionary Approach. Edited by A. R. Hoelzel. Blackwell Publishing, Oxford.

Brabyn, M. W. 1991. An analysis of the New Zealand whale stranding record. New Zealand Department of Conservation, Wellington, Science and Research Series 29: 1-47.

Brabyn, M. W., and I. G. McLean. 1992. Oceanography and coastal topography of herd-stranding sites for whales in New Zealand. Journal of Mammalogy 73: 469-476.

Cordes, D. O. 1982. The causes of whale strandings. New Zealand Veterinary Journal 30: 21-24.

Culik, B. M., S. Koschinski, N. Tregenza, and G. M. Ellis. 2001. Reactions of harbor porpoises Phocoena phocoena and herring Clupea harengus to acoustic alarms. Marine Ecology Progress Series 211: 255-260.

Dailey, M. D., and W. A. Walker. 1978. Parasitism as a factor (?) in single strandings of southern California cetaceans. Journal of Parasitology 64: 593-596.

Dudok van Heel, W. H. 1962. Sound and cetacea. Netherlands Journal of Sea Research 1: 407-507.

Engel, M. H., M. C. C. Marcondes, C. C. A. Martins, F. O Luna, R. P. Lima, and A. Campos. 2004. Are seismic surveys responsible for cetacean strandings? An unusual mortality of adult humpback whales in Abrolhos Bank, northeastern coast of Brazil. International Whaling Commission Document SC/56/E28.

Evans, P. G. H., and P. S. Hammond. 2004. Monitoring cetaceans in European waters. Mammal Review 34: 131156.

Evans, K., R. Thresher, R. M. Warneke, C. J. A. Bradshaw, M. Pook, D. Thiele, and M. A. Hindell. 2005. Periodic variability in cetacean strandings: links to large-scale climate events. Biology Letters 1: 147-150.

Félix, F., B. Haase, J. W. Davis, D. Chiluiza, and P. Amador. 1997. A note on recent strandings and bycatches of sperm whales (Physeter macrocephalus) and humpback whales (Megaptera novaeangliae) in Ecuador. Report of the International Whaling Commission 47, SC/48/O 14: 917-919.

Fernández, A., J. F. Edwards, F. Rodríguez, A. Espinosa de los Monteros, P. Herráez, P. Castro, J. R. Jaber, V. Martin, and M. Arbelo. 2005. "Gas and fat embolic syndrome" involving a mass stranding of beaked whales (family Ziphiidae) exposed to anthropogenic sonar signals. Veterinary Pathology 42: 446-457.
Ferrero, R. C., and L. M. Tsunoda. 1989. First record of a bottlenose dolphin (Tursiops truncatus) in Washington State. Marine Mammal Science 5: 302-5.

Ferrero, R. C., J. Hodder, and J. Cesarone. 1994. Recent strandings of rough-toothed dolphins, Steno bredanensis, on the Oregon and Washington coasts. Marine Mammal Science 10: 114-6.

Gearin, P. J., S. R. Melin, R. L. DeLong, H. Kajimura, and M. A. Johnson. 1994. Harbor porpoise interactions with a Chinook salmon set-net fishery in Washington State. Report of the International Whaling Commission (special issue) 15: 427-38.

Geraci, J. R. 1978. The enigma of marine mammal strandings. Oceanus 21: 38-47.

Geraci, J. R., and V. J. Lounsbury. 2005. Marine mammals ashore: a field guide for strandings. National Aquarium in Baltimore. 372 pages.

Goold, J. C., H. Whitehead, and R. J. Reid. 2002. North Atlantic sperm whale, Physeter macrocephalus, strandings on the coastlines of the British Isles and eastern Canada. Canadian Field-Naturalist 116: 371-388.

Grand Manan Whale and Seabird Research Station. (GMWSRS). 2001. Guidelines for releasing harbour porpoises and other whales from herring weirs. Grand Manan Whale and Seabird Research Station Bulletin 3. 12 pages.

Hill, T., and P. Lewicki. 2006. Statistics: Methods and Applications. StatSoft. 832 pages.

Hooker, S. K., R. W. Baird, and M. A. Showell. 1997. Cetacean strandings and bycatches in Nova Scotia, eastern Canada, 1991-1996. International Whaling Commission Document SC/49/05.

Hooker, S. K., H. Whitehead, and S. Gowans. 1999. Marine protected area design and the spatial and temporal distribution of cetaceans in a submarine canyon. Conservation Biology 13: 592-602.

Jauniaux, T., L. Brosens, E. Jacquinet, D. Lambrigts, and F. Coignoul. 1997. Pathological investigations on sperm whales stranded on the Belgian and Dutch coasts. Biologie 67 (Supplement): 63-67.

Johnson, A., G. Salvador, J. Kenney, J. Robbins, S. Kraus, S. Landry, and P. Clapham. 2005. Fishing gear involved in entanglements of right and humpback whales. Marine Mammal Science 21: 635-645.

Joiris, C. R., L. Holsbeek, M. Bossicart, and G. Tapia. 1997. Mercury and organochlorines in four sperm whales stranded on the Belgian coast, November 1994. Biologie 67 (Supplement): 69-73.

Kenyon, K. W. 1961. Cuvier beaked whales stranded in the Aleutian Islands. Journal of Mammalogy 42: 71-76.

Ketten, D. R. 1991. The marine mammal ear: specializations for aquatic audition and echolocation. Pages 717-754 in The Evolutionary Biology of Hearing. Edited by D. Webster, R. Fay, and A. Popper. Springer-Verlag, New York.

Ketten, D. R. 1994. Functional analyses of whale ears: adaptations for underwater hearing. IEEE Proceedings in Underwater Acoustics 1: 264-270.

Klinowska, M. 1985. Interpretation of the UK cetacean stranding records. Report of the International Whaling Commission 35: 459-467.

Lawson, J. W., and J. D. Eddington. 1998. A first eastern Canadian stranding record for Risso's Dolphin, Grampus griseus. Northeastern Naturalist 5: 215-218.

Le Boeuf, B. J., M. H. Pérez-Cortés, R. J. Urbán, B. R. Mate, and U. F. Ollervides. 2000. High gray whale mortality and low recruitment in 1999: potential causes and 
implications. Journal of Cetacean Research and Management 2: 85-99.

Lucas, Z. N., and S. K. Hooker. 2000. Cetacean strandings on Sable Island, Nova Scotia, 1970-1998. Canadian FieldNaturalist 114: 45-61.

Maldini, D., L. Mazzuca, and S. Atkinson. 2005. Odontocete stranding patterns in the main Hawaiian Islands (19372002): how do they compare with live animal surveys? Pacific Science 59: 55-67.

McAlpine, D. F. 1985. First records of the Sperm Whale (Physeter macrocephalus) from New Brunswick and the Bay of Fundy. Le Naturaliste canadien 112: 433-434.

McAlpine, D. F., and M. Rae. 1999. First confirmed reports of Beaked Whales, cf. Mesoplodon bidens and M. densirostris (Ziphidae) from New Brunswick. Canadian FieldNaturalist 113: 293-295.

McAlpine, D. F., L. D. Murison, and E. P. Hoberg. 1997. New records for the Pygmy Sperm Whale, Kogia breviceps (Physeteridae) from Atlantic Canada with notes on diet and parasites. Marine Mammal Science 13: 701-704.

McAlpine, D. F., M. C. S. Kingsley, and P.-Y. Daoust. 1999. A lactating record-age St. Lawrence Beluga (Delphinapterus leucas). Marine Mammal Science 15: 854-859.

Mignucci-Giannoni, A. A., S. Toyos-González, J. PérezPadilla, M. A. Rodríguez-López, and J. Overing. 1999. Mass stranding of pygmy killer whales (Feresa attenuata) in the British Virgin Islands. Journal of the Marine Biological Association of the UK 80: 759-760.

Mitchell, E. D., and V. M. Kozicki. 1975. Autumn stranding of a northern bottlenose whale (Hyperoodon ampulluatus) in the Bay of Fundy, Nova Scotia. Journal of the Fisheries Research Board of Canada 32: 1019-1040.

Neave, D. G., and B. S. Wright. 1968. Seasonal migrations of the Harbor Porpoise (Phocoena phocoena) and other cetacea in the Bay of Fundy. Journal of Mammalogy 49: 259-264.

Nelson, D., and J. Lien. 1996. The status of the long-finned pilot whale, Globicephala melas, in Canada. Canadian Field-Naturalist 110: 511-524.

Norman, S. A., M. M. Muto, D. J. Rugh, and S. E. Moore. 2000. Gray whale strandings in 1999 and a review of stranding records in 1995-1998. Paper SC/52/AS5 presented to the International Whaling Commission Scientific Committee, June 2000, Adelaide, Australia. 36 pages.

Norman, S. A., C. E. Bowlby, M. S. Brancato, J. Calambokidis, D. Duffield, P. J. Gearin, T. A. Gornall, M. E. Gosho, B. Hanson, J. Hodder, S. J. Jeffries, B. Lagerquist, D. M. Lambourn, B. Mate, B. Norberg, R. W. Osborne, J. A. Rash, S. Riemer, and J. Scordino. 2004. Cetacean strandings in Oregon and Washington between 1930 and 2002. Journal of Resource Management 6: 8799.

Northridge, S. P. 1991. An updated world review of interactions between marine mammals and fisheries. FAO Fisheries Technical Paper (734), Suppl. 1. Food and Agriculture Organization of the United Nations, Rome, Italy. 58 pages.

Osborne, R. W., and T. W. Ransom. 1988. Two rare strandings in Washington state. Cetus 8: 24-5.

Parsons, E. C. M., I. Birks, P. G. H. Evans, J. C. D. Gordon, J. H. Shrimpton, and S. Pooley. 2000. The possible impacts of military activity on cetaceans in West Scotland. European Research on Cetaceans 14: 185-190.

Payne, P. M., and D. W. Heinemann. 1993. The distribution of pilot whales (Globicephala spp.) in shelf/shelf- edge and slope waters of the northeastern United States, 1978-1988. Report of the International Whaling Commission. Special Issue 14: 51-68.

Piers, H. 1923. Accidental occurrence of the Pygmy Sperm Whale (Kogia breviceps) on the coast of Nova Scotia: an extension of its known range; with remarks on the probability of the former presence in these waters of the true Sperm Whale (Physeter macrocephalus). Proceedings of the Nova Scotia Institute of Science 15: 95-114.

Reeves, R. R., B. S. Stewart, P. J. Clapham, and J. A. Powell. 2002. National Audubon Society Guide to Marine Mammals of the World. Alfred A. Knopf, New York.

Sergeant, D. E. 1982. Mass strandings of toothed whales (Odontoceti) as a population phenomenon. The Scientific Reports of the Whales Research Institute 34: 1-47.

Simmonds, M. P., and L. F. Lopez-Jurado. 1991. Whales and the military. Nature 351: 448.

Sundaram, B., A. C. Poje, R. R. Veit, and H. Nganguia. 2006. Acoustical dead zones and the spatial aggregation of whale strandings. Journal of Theoretical Biology 238: 764-770.

Trippel, E. A., J. Y. Wang, M. B. Strong, L. S. Carter, and J. D. Conway. 1996. Incidental mortality of harbour porpoise (Phocoena phocoena) by the gill-net fishery in the lower Bay of Fundy. Canadian Journal of Fisheries and Aquatic Sciences 53: 1294-1300.

Trippel, E. A., M. B. Strong, J. M. Terhune, and J. D. Conway. 1999. Mitigation of harbour popoise (Phocoena phocoena) by-catch in the gillnet fishery in the lower Bay of Fundy. Canadian Journal of Fisheries and Aquatic Sciences 56: 113-123.

Vanselow, K. H., and K. Ricklefs. 2005. Are solar activity and sperm whale Physeter macrocephalus strandings around the North Sea related? Journal of Sea Research 53: 319-327.

Walker, R. J., R. O. Keith, A. E. Yankovsky, and D. K. Odell. 2005. Environmental correlates of cetacean mass stranding sites in Florida. Marine Mammal Science 21: 327-335

Walsh, M. T., D. Beusse, W. G. Young, J. D. Lynch, E. D. Asper, and D. K. Odell. 1991. Medical findings in a mass stranding of pilot whales (Globicephala macrorhynchus) in Florida. Pages 75-83 in Marine Mammal Strandings in the United States. Proceedings of the Second Marine Mammal Stranding Workshop, Miami, Florida, December 3-5, 1987. Edited by John E. Reynolds, III, and Daniel K. Odell. NOAA Technical Report NMFS 98.

Weilgart, L. S. 2007. A brief review of known effects of noise on marine mammals. International Journal of Comparative Psychology 20: 159-168.

Whitehead, H. 2003. Sperm Whales: Social Evolution in the Ocean. University of Chicago Press, Chicago and London. 431 pages.

Wimmer, T. 2003. Distribution of cetaceans on the continental shelf break off Nova Scotia and in adjacent waters with a focus on northern bottlenose whales (Hyperoodon ampullatus). Master's thesis, Dalhousie University, Halifax, Nova Scotia, Canada.

Wright, A. J. 2005. Lunar cycles and sperm whales (Physeter macrocephalus) strandings on the North Atlantic coastlines of the British Islas and eastern Canada. Marine Mammal Science 21: 145-140.

Received 3 August 2009

Accepted 28 May 2010 